Published in Environmental Education Research 15(6) 643-659

\title{
Responding to environmental challenges - An assessment of higher education curricula needs by Australian planning professionals
}

\author{
A.C. Hurlimann ${ }^{\mathrm{a}}$ \\ aFaculty of Architecture Building and Planning, The University of Melbourne, Melbourne Australia.
}

\begin{abstract}
Urban planners have a key role to play in the facilitation of sustainable development. Environmental planning education has become crucial given the projected implications of climate change for human settlements and nature. However, despite the identified importance of educating planners with regards to sustainability and environmental issues, there has been limited discussion of the topic within literature. In particular, there has been little consultation with planning professionals about their perception of environmental planning curricula needs. This paper addresses this need through the survey of planning professionals in Australia. Perceived gaps in environmental knowledge and skills of planners were identified. The key knowledge gaps highlighted included climate change and water management. The key skill gaps highlighted included critical thinking and independent inquiry. Implications for urban planning curricula including the need to revise planning curricula are discussed. The study has implications for and interest to other professional degrees of which environmental sustainability is a component.
\end{abstract}

Keywords: curriculum, urban planning, environment, sustainability, professionals, consultation, Australia

\section{Environmental sustainability - challenges for urban planners}

The world is facing significant environmental challenges including species extinction, loss of biodiversity, water scarcity, rising temperatures, and increasing pollution. A number of these challenges are a result of, or linked to anthropologically driven climate change (Intergovernmental Panel on Climate Change 2007). These environmental

\footnotetext{
a Email: HUanna.hurlimann@unimelb.edu.auUH
} 
challenges and in particular climate change have implications for the way in which urban areas are planned and managed, in particular to mitigate the extent to which climate change occurs, and adapt to altered climate. Urban planning (planning) has been recognized by many scholars as one profession which can make a positive contribution towards achieving sustainable development (Beatley and Manning 1998; Niebanck 1993; Thompson 2007; Wheeler 2004). At the same time, there is recognition of the many challenges faced by planners when implementing the goals of sustainability (Campbell 1996). Conflicts occur between the various definitions of sustainability (more than threehundred), and their differing goals (see Dobson 1996). Additionally, it has been recognized that in the Australian and New Zealand context there has been limited uptake of environmental sustainability in the education of planners (Gunder 2006).

The concept of sustainable development was elevated to the world stage by the World Commission on Environment and Development (WCED 1987). The WCED's definition was very broad and encompassed goals surrounding ecology, economics, politics, ethics, participation, intragenerational equity and intergenerational equity. To aid the assessment of the many goals of sustainability, they are often condensed into three categories: social, economic and environmental using the 'triple bottom line' approach (Elkington 1997). When making assessments on such condensed categories, compromises often result, and the environmental components of sustainability are often neglected (Carroll 2005; Diesendorf 1997; McManus 1996). Rapport (1995) argues that ecosystem health is the "bottom line" guiding sustainable development, because if the health of the environment is compromised, then everything else is undermined. As such, it is critical that urban planners have a sound understanding of the importance of the environmental components of sustainable development and the ability to negotiate this within the context of other competing interests. Martin and Beatley (1993) argue that given the focus of planning on managing land use and human settlement patterns, coverage of environmental ethics and sustainability in planning curricula is essential for providing normative guidance to planners and others involved in the planning process.

Review of the planning education literature reveals limited discussion about the environmental education of planners. As such, literature from the broader areas of 'environmental education' and 'education for sustainability' have also been drawn upon for this research. In this paper the distinction between 'education for sustainability' and 
'environmental education' is made in line with Sherran (2008a) who acknowledges that most commentators acknowledge 'environmental education' is education about the environment, where as 'education for sustainability' is education for the environment. Both of which are of interest to this study. A key focus of this research was to investigate educational gaps for urban planners in Australia as perceived by planners (planning professionals). Specifically, this research focused on establishing the perceived gaps relating to environmental education of planners, and identifying priority curriculum needs. This paper begins by outlining the profession of urban planning, and describes the history of planning education. The increasing importance of environmental education is then presented. The research methodology employed is then outlined, followed by the presentation and discussion of results and the implications of these.

\section{Planning and the education of the profession}

The profession of planning has been described by many terms including, urban planning, town planning, town and country planning, and urban and regional planning. The definition of planning adopted for this paper is that defined by the Australian Bureau of Statistics (2006), "urban and regional planners develop and implement plans and policies for the controlled use of urban and rural land, and advise on economic, environmental and social needs of land areas." However, internationally there is disagreement about how planning is defined (Marshall 2007; Thompson 2007). Thompson (2007) believes that the many definitions of planning that exist, mirror the traditions of thought and historical development of planning and the disciplines from which it draws. Marshall (2007) contends that many planning organizations change their definition regularly to reflect social, economic, political and ideological influences at points of time. Indeed specialties within the profession of planning have arisen in response to particular problems (Wheeler 2004). Emerging in the early 1900s, the profession of planning aimed to improve amongst other aspects, the health, efficiency, and beauty of cities (Freestone 2007). Subsequent concerns to emerge have included land use regulation and zoning, regional economic development, environmental planning, and sustainable development (Wheeler 2004). The professionalization of planning occurred as part of the general progress of public serviceoriented professionals, and was closely linked to urban and social reform movements before and after the first world war (Marshall 2007). Marshall (2007) describes the professional culture of planning as being underpinned by shared values in relation to social, economic and environmental planning and the production of places in which to live and 
work. Indeed, as described by Gleeson and Low (2000), planning means different things at different times and in different places.

There has been much debate about the education of planners. As described by Alonso (1986), planning education has experienced three major phases: an architectonic phase; a profession focused phase; and a diversifying phase. The first courses in city planning were offered in 1909 in the USA at the departments of landscape architecture at Harvard University and the University of Illinois, and later spread to other universities throughout the world (Alonso 1986). By the 1960s there were twenty-two planning schools, who predominantly offered two to three year postgraduate degrees graduating a total of only about one-hundred students a year (Alonso 1986). Half the students had already earned degrees in architecture or civil engineering. Alonso (1986) raised many criticisms of planning education at this time, arguing that planners failed to successfully address the urban challenges that existed in the 1950s and 1970s, due to their limited education in sociology. The focus of planning education at that time was on practice, and specifically in design, and site project planning (Perloff 1956). In the 1950s, Perloff (1956) called for the engagement of economists, sociologists, geographers, and political scientists in the education of planners. He also called for the academizing of planning - and for engagement in research.

In Australia, the first planning course began in Adelaide in 1949 at the South Australian School of Mines and Industries (Hamnett 1999). While the demand for planning education escalated from that point until the 1990s, there has been a documented decline in student enrolment in planning courses throughout Australia (Vipond 2000). Hamnett (1999) believes that the closure of planning schools in the 1990s, coupled with others being under threat, has caused remaining schools to reinvent themselves around expanded and eclectic curricula. The most common features of these reinvented curricular are a concern for environmental issues and ethics, and a reborn interest in urban design (Hamnett 1999).

Contemporary planning curriculum is diverse, and thus continues to lead to questions about the core skills that planners require (Hamnett 1999). Sandercock (1997) believes that professionally driven planning education has a tendency to reduce knowledge and understanding to a shopping list of skills, methods and competencies. A more 
helpful approach Sandercock (1997) argues, would be to establish the kinds of qualities professionals would like to see in graduates. Sandercock advocates five literacies for future planners to be equipped with: technical, analytical, multi/cross cultural, ecological and design. In Australia discussions about the links planning education has to professional practice are ongoing in literature and in the professional associations. Kerkin (2000) acknowledges that planning education has been criticized by various academics as contributing to a skills based 'professional' education rather than a critical education based firmly in the social sciences. As described earlier, practical experience was traditionally the fundamental part of planning curricular decades ago (Kotval 2003) and continues to be described as an applied professional study by some authors (for example Freestone et al. 2007).

Perloff's (1956) seminal work on planning education advocated three key elements of planning core curriculum:

1) Basic knowledge: Hypotheses, theories, and principles. Focus was on the planning process, urbanism and the urbanization process, physical elements of planning, and socio-economic elements of planning.

2) Basic methods and tools: analytical; design.

3) Problem solving experiences: case studies, individual problems, group "workshop" problems.

In an update to Perloff's work, Feldman (1994) proposed broadening planning education beyond professional planning and to do so by aligning planning's academic focus along traditional academic lines. Feldman advocates less emphasis on education for the profession to facilitate a more diverse learning community, moving away from using the planning profession as the criteria by which to define what constitutes planning. This continuing discussion about planning education is related to that of the increasing imperative of environmental education.

In Australia at present there are 7505 planning practitioners (Australian Council of the Built Environment Design Professions Ltd 2008). The Planning Institute of Australia (PIA), are the peak professional planning body in Australia, and accredit 25 undergraduate and 28 graduate planning degrees across the country (PIA 2009). Accreditation occurs in line with the PIA Education Policy (PIA 2002). This policy includes an appendix of 'Core Curriculum in Planning' which includes a list of required knowledge fields, skill areas, and the adoption of professional ethics. The five knowledge areas include but are not limited to: 'principles of ecologically sustainable development', 
and 'relevant social, economic and environmental principles.' The 14 skills listed appear to be limited, they include: 'understanding policy formulation, evaluation and implementation' and 'knowledge synthesis and application in planning practice.' The increased importance of environmental education will now be discussed.

\section{The increasing importance of environmental education}

Environmental education has developed in response to a number of factors including the acknowledged decline in environmental condition world wide, which is coupled with rising awareness of the prominence of global environmental issues (Lim 1993). The increasing importance of environmental issues has given rise to a number of environmental education initiatives at various scales.

Wright (2004) details and critiques the international evolution of sustainability declarations in higher education. As discussed by Wright (2004), there were a number of charters and declarations in the 1970s which were influential to the development of international environmental and sustainability education initiatives. These include the Tbilisi Declaration of 1977, and the Belgrade Charter of 1975. The Talloires Declaration is a significant international declaration regarding the importance of environmentally sustainable education at universities. The declaration was created in October 1990 in Talloires France when twenty two university presidents and chancellors from various nations met and voiced their concerns about the state of the world's environment (Association of University Leaders for a Sustainable Future (AULSF) 1994). The document specifies key actions institutions of higher education must take to create a sustainable future. As of January 2008, the Talloires Declaration had been signed by more than three hundred and sixty university presidents and chancellors at institutions in over forty countries (AULSF 2008). Further information about the Tallories declaration, including an assessment of the extent to which Australian Higher education institutions have taken this on board is provided by Holdsworth et al. (2008).

In 2000, the Australian Government created the National Environmental Education Council. The Council's role is to facilitate incorporation of sustainability into university curricula and to encourage universities to improve environmental management within their own institutions (Bekessy et al. 2003). Sponsored by the Australian Conservation Foundation, Bekessy et al. (2003) produced a report on universities and sustainability, with the aim of 
facilitating the achievement of more sustainable practices. The report recommends a multifaceted approach to achieve sustainability which includes the integration of sustainability across curriculum. In December 2002, the United Nations General Assembly adopted resolution 57/254 to implement the United Nations (UN) Decade of Education for Sustainable Development (DESD) 2005-2014 (UNESCO 2008). The aim of this program was to challenge people to adopt new behaviors and practices which promote sustainability through education. The DESD seeks to promote: interdisciplinary and holistic learning; values-based learning; critical thinking; multi-method approaches; participatory decision-making; and locally relevant information.

Despite the educational initiatives described, environmental education has not been widely facilitated in Australia. A recent study by Lang et al. (2006) investigated the extent to which higher education institutions in Australia include 'education for sustainability' in their curricular via evidence on their web sites. Out of forty-two institutions, only twelve had evidence of education for sustainability on their web site (eight of those had signed the Talloires Declaration), and ten had evidence of this in their curriculum (for example in graduate attributes). There are many potential barriers to this apparent lack of environmental education. Noonan and Thomas (2004) discuss barriers to implementing sustainability into curricula. These include issues of governance, advocacy and leadership, communication, economic challenges, and policy inadequacy. Smyth (2006) believes a barrier to achieving a fundamental educational reform required for environmental education is the disciplinary structure of most post-primary formal education.

\section{Planning and Environmental Education}

A review of planning and environmental literature revealed limited prior research on the topic of environmental education of planners. Due to the limited work directly in the field of environmental education of planners, literature from other fields of environmental education is therefore important. While there have been significant initiatives to include greater emphasis on education for sustainability (as discussed in section 2 of this paper), Sherran (2006) has found that sustainability is not yet well integrated in specialist or generalist coursework programs in Australia. 
The limited work conducted in this field of environmental education of planners includes that by Niebanck (1993), who identified a number of educational implications for planners, dividing them into four skill modes: rule making, principled action, targeted action and place making. Niebanck (1993) questions whether environmental planning education draws sufficiently from other fields such as anthropology, cultural studies and ecology. An additional question raised by Niebanck (1993) is whether previously neglected skill areas need to be revisited (such as negotiation, arbitration, and conflict resolution, professional and environmental ethics). Niebanck (1993) believes that environmental planning education is in the applied and critical dimensions of the social sciences and calls for environmental planning education to be extended into other fields, including those that explore the motivational and behavioral aspects of human life.

A key question regarding the environmental education of planners is whether environmental knowledge or general skills of implementation and analysis are more important. Sherran (2008b) believes critical elements of sustainability education are humanist graduate characteristics, such as critical thinking, independent inquiry, problem solving, creativity, sensitivity, empathy, foresight, self-expression and broadened perspectives. In an analysis of Australian programs educating for sustainability Sherran's (2008a) identified that a rebalancing towards the human element is necessary to educate for sustainability as compared with simply the 'environment'. Sherran (2006) believes that education that encourages critical thinking is a key to education for sustainability. Thus, four key elements to the education of sustainability generalists are advocated: liberal education; interdisciplinarity, cosmopolitanism and civics (Sherran 2006).

In line with the key components of education for sustainability advocated by Sherran (2006), Stevenson (2007) argues students should be exposed to the plurality of environmental ideologies, and that through a process of inquiry, critique and reflection they can be assisted to develop and defend their own set of environmental beliefs and values. Such an approach is also advocated by Martin and Beatley (1993). Stevenson (2007) believes that if students are to be capable of acting on their choices and influencing environmental decision making, then environmental education must incorporate the development of students' knowledge of the political-legal process and skills in political advocacy. Furthermore Stevenson (2007) believes students should be encouraged to analyze the 
various forms of political participation so that they can rationally justify the strategies for action which will employ their advocacy skills. Affective attributes have also been identified as critical in the area of education for sustainability. These include but are not limited to systems thinking (Cohen 2007), affective outcomes such as values, attitudes and behaviour (Shephard 2008), and environmental advocacy (Jickling 2003).

While there is limited direct literature on planning and environmental education, there are other key planning curriculum issues for other topics which have implications for considering the role of environmental education within planning. One such issue is diversity. Kwitko and Thompson (2002) investigated cultural inclusivity within the context of Australian and New Zealand planning schools. They found two major approaches to incorporating diversity awareness into planning education have been utilised: 1) the design of specific courses and 2) integration throughout the curriculum. Their research identified that both approaches pose challenges. Specific courses may lead to marginalisation of the issue, whereas integration raises concerns about the ability to encompass disparate understandings and acceptance of diversity across all staff (Kwitko and Thompson 2002). Wolfe (2001) has researched environmental education in non-environmental fields and found that when students take environmental subjects from multiple departments, their experience is disrupted.

The discussion of planning, sustainable development and environmental issues presented gives rise to the following research questions: 1) Do planning professionals perceive there are knowledge and / or skill gaps in the area of environmental education for planners in Australia? ${ }^{b}$ 2) If so, what is the nature of these gaps? 3) For planners to address environmental problems, do planning professionals perceive 'knowledge' or 'skills' to be more important? These research questions were addressed through a survey of planning professionals in Australia.

\section{Method}

The majority of studies regarding environmental education at universities from various countries have involved surveys of academic opinion (Bekessy et al. 2003; Lang et al. 2006; Martin and Beatley 1993; Noonan and

\footnotetext{
${ }^{b}$ For the purpose of this research the following definitions from Brockmann (2008) are used: 'knowledge' is defined as theoretical knowledge 'knowing what'; skills are defined as 'knowing how' and the development of more personal attributes such as problem solving, independent decision making.
} 
Thomas 2004; Wolfe 2001). As identified by Cooke et al. (2006), employer demands and expectations of graduates at course completion should not be ignored when developing professional courses. Importantly it has been recognized that a key component of curriculum design is consultation with experts, including representatives from professional associations (Biggs and Tang 2007; Ramsden 2003; Toohey 1999). This study seeks to compliment the existing data from consultation with academics through consultation with planning professionals in addition to academics.

In order to address the identified research questions, planning practitioners across Australia were surveyed in the months of September and October 2008. The survey was conducted online using Zoomerang survey software. Respondents were recruited through advertisements in the PIA national monthly email newsletter (October), and through the Victorian PIA weekly email newsletter in September. These advertisements provided a brief overview of the study with a link to the survey web page. Recruitment also occurred through direct email invitations to planning professionals known to the researcher. Participation was voluntary and anonymous. The survey was divided into three main components: 1) questions regarding general gaps in respondents' education and the education of their colleagues, 2) questions specific to environmental education of planners (knowledge and skills), and 3) general demographic / work history details for each respondent. The survey contained both qualitative and quantitative (ranking and rating) questions. Various conventions for coding and analysing qualitative data were followed for this component of the research (Babbie 2008; Marshall 2002; Richards 2005). Coding was conducted manually (in excel) twice to verify coding results. The SPSS program was used to store and analyse the quantitative aspects of the results.

\section{Results and Discussion}

In total fifty respondents completed the survey. While this is a small proportion of the total number of planning practitioners in Australia, the sample size is considered appropriate for this predominantly qualitative study (Sandelowski 1995). However, future research to increase the sample size would be beneficial. The study does not seek to make statements from the results that indicate representativeness of the opinions of all planners in Australia. Respondents were from a diverse range of backgrounds as displayed in Table 1 giving a good cross section of 
opinion from which to draw upon. On average respondents had been working as a planner for 11 years (standard deviation $=9$ years $)$. Most $(n=42)$ hold a planning degree $(5$ did not, and 3 did not respond). The respondents were predominantly from the state of Victoria $(n=34)$, perhaps reflecting more extensive promotion of the study in this, the authors home state. Urban areas were the dominant location, and respondents were predominantly in private practice or local government. Twenty-two respondents stated they had responsibility for managing staff.

Insert Table 1

\subsection{General knowledge gaps}

Respondents were asked if they considered there to be shortfalls in current planning education in Australia. In total 35 respondents replied yes, 4 no, and 11 did not know. Those respondents who perceived there were gaps were then asked to detail these shortfalls. Responses from this open ended question were coded into categories as displayed in Table 2. As can be seen from this table the main gap identified was environmental issues $(n=10)$. Specific examples of shortfalls respondents identified and which fell into the 'other' category, included:

"Confidence to educate and enforce environmental issues with the public"

"There is a lack of understanding of social-ecological interactions, because of the legacy of engineering and management paradigms"

Insert Table 2

The second largest gap identified was a disconnection between education and practice $(n=5)$. For example, one respondent commented that "lecturers do not have practical experience", while others indicated this differed from course to course: "some courses lack practical experience, others focus too much on this at this at the expense of theory". Five respondents identified an absence of critical thinking, including comments such as the following: 
"Planners are not taught to think philosophically and critically"

"There is very little education on ...balanced decision making"

\subsection{Environmental knowledge}

In a quantitative structure, twelve environmental knowledge areas were presented to respondents. These knowledge areas were developed from discussions observed by the author at national planning professional events and in literature regarding environmental issues. Respondents were asked if they perceive planners to be adequately educated with knowledge (in each of the 12 areas) in order to fulfill their required capacity as planners. The respondents were asked to indicate if they perceived each knowledge area to be: inadequate; adequate; or more than adequate (Figure 1). Overall the following eight knowledge fields were rated as having inadequate knowledge by more than $50 \%$ of respondents): sustainable building design; planning for biodiversity; sea level rise ${ }^{c}$; climate change - social implications / adaptation / mitigation; water sensitive urban design; and water management and policy.

Insert Figure 1

Respondents were then asked if there were any other specific environmental knowledge areas they feel planners are not adequately educated about (open ended format). Twenty nine responses were provided. These responses each raised very specific knowledge gaps, for example:

"... the question of how to balance (or whether you should even try to balance) economic resilience, social equity, and environmental outcomes"

"There needs to be a more systems thinking approach to planning education"

"Facilitating the cultural change needed to proactively and effectively plan for / positively influence environmental issues rather than reactive planning which is only possible with current social priorities and awareness"

c Sea level rise and climate change were separated in this study, due to the explicit planning implications of sea-level rise. For a discussion of planning implications of sea level rise see Vasey-Ellis (2009) 
"Planning law issues that are outside the realm of the Victorian planning provisions. Common law issues associated with planning such as the doctrine of accretion are not addressed in planning law courses and they need to be since planners may face these issues in their jobs and have no understanding of what they're about. Coastal planning in general is not adequately educated for in the Universities"

These responses acknowledge the complexity of sustainability, and the conflicts that arise for planners as discussed in earlier sections of this paper. In the next section of the survey, respondents were asked which knowledge area they believed should be addressed as a priority, and why. The responses were coded and categorized, the results of which are detailed in Table 3. The knowledge area which was identified by the greatest number of respondents as a gap to be addressed as a priority was climate change, followed secondly by water management.

Insert Table 3

\subsection{Environmental skills}

In a quantitative structure, eleven environmental skill areas developed from the work of Sherran (2008b) and Stevenson (2007) were presented in the survey. For each skill, respondents were asked if they perceive planners to be adequately educated. The respondents were asked to indicate if they perceive each skill area to be: inadequate; adequate; or more than adequate. Just two of the skill areas were rated as inadequate by more than fifty per cent of respondents: skills in political advocacy and broadened perspectives (Figure 2).

Insert Figure 2 
Provision was made for respondents to identify other environmental skill areas they felt planners were not adequately educated in. Twelve respondents provided comments, most of which pointed to specific skills such as the following:

"The ability to understand and translate basic scientific principles (e.g. waste management) into policy or communicate that information in plain English"

"To read plans and to understand urban design issues"

"What planners' role is. Their limitations with regard to knowledge and skills - and legislative background"

Respondents were asked which skill areas they believe should be addressed as a priority and why (a small number of respondents provided more than one skill area to be addressed as a priority). Responses are detailed in Table 4. Critical thinking was rated by thirteen respondents as the priority skill area to address.

Insert Table 4

\subsection{Environmental knowledge versus skills}

Respondents were asked if they perceive knowledge or skills as more important for planners to possess in order to address environmental problems. In total, twenty one respondents rated both knowledge and skills to be of equal importance, fifteen rated skills as more important, six rated knowledge as more important and eight did not know, or did not respond. The opportunity to make further comments about the environmental education of planners was provided. There were a number of responses with varied messages. Examples include the following:

"I think that skills are more important than knowledge as it is the role of scientists' and other specialist fields to have this knowledge and it is the role of planners to understand enough of the 'knowledge' to use their 'skills' to implement the required actions" 
"Planners are generalists and are not experts in environmental awareness but they have to be given the skills and knowledge to weigh the evidence, establish and interpret it and develop legally sound underpinnings if policy interventions are to be effective"

"We need to recognize that planning education is about teaching a way of thinking, so that we are equipped with the basics and we know how to analyze various problems as they arise. It will also never be possible to include everything in a single planning degree course - lifelong learning is essential."

\subsection{Implications of the study results}

The comments presented in section 6.4 of this paper indicate the belief of a number of respondents that skills are more important for planners to possess than specific knowledge in order to address environmental problems. The results also align with the various opinions about the role of planning discussed in section two of this paper and to the discussion in section 1 regarding planning having been recognized by a number of scholars (Beatley and Manning 1998; Niebanck 1993; Thompson 2007; Wheeler 2004) as one profession which can make a positive contribution towards achieving sustainable development. Interlinked with this, is the discussion of 'education for sustainability' discussed in section 3, which highlighted the importance of the development of skills, affective attributes and personal development (Sherran 2006, 2007, 2008a, 2008b, Martin and Beatley 1993, Stevenson 2007, Cohen 2007, Shephard 2008 and Jickling 2003). This theory regarding education for sustainability has been verified by planning practitioners who participated in this study. However, it could be argued that planners must have an extent of environmental literacy to be able to adequately and accurately apply their skills to these issues. It is argued that possession of research and analytical skills, accompanied by specific knowledge in one or two environmental areas will equip planners well with the skills to address environmental challenges, in line with that advocated by Sherran (2008).

The findings of this research indicate the need to update both current urban planning curriculum in Australia, and to offer continual education modules for planners in practice (who have already graduated), to address the knowledge and skill gaps identified. Further research is required to establish the best way to facilitate this, and is anticipated to vary from institution to institution depending on the existing course structure and opportunities which 
are presented in other programs. When considering revisions to curriculum, the findings of Wolfe (2001) should be considered to avoid disrupted experiences for students taking subjects from multiple faculties. Additionally in line with the findings of Kwitko and Thompson (2002), Martin and Beatley (1993) and of constructive alignment advocated by Biggs and Tang (2007), it is recommended that aspects of the course be mutually reinforced through other subjects offered in the degree. This implies the need for curriculum revision across programs.

Another implication arising from this research is that the skill gaps identified should be addressed. Once again, further research is required to establish how this would best be achieved. It is proposed that this could be facilitated through multiple subjects within urban planning curriculum, and those offered as continual education to planners in practice. It is proposed that the skill gaps critical thinking, independent inquiry and broadened perspectives should be addressed in most subjects, as the skills are applicable to all knowledge areas (not just environmental knowledge areas). Specific teaching and learning activities in subjects should aim to develop competency in these specific skill areas. There would also be benefit in directly addressing these skill areas in environmental / sustainability subjects.

One possible criticism of this recommended knowledge addition to planning education is that it is simply a reaction to issues of importance / public interest at the time of survey. In response to this anticipated criticism, it is argued that these environmental issues have been in the public domain since the 1960s (Carson 1963; Meadows et al. 1972; World Commission on Environment and Development 1987). However, it is clear from this research that despite over forty years of public awareness of these as environmental issues, Australian urban planning education has not adequately addressed these needs as identified in the survey of planning professionals. Martin and Beatley (1993) believe planning faculty are lagging behind the perceived interests and needs of their students in regards to environmental and sustainability education.

\section{Conclusions}

This study sought to consult with planning professionals about whether or not they perceived environmental knowledge or skill gaps exist in the education of planners, and if so, to investigate the nature of these gaps. This 
paper has demonstrated that survey respondents identified a number of knowledge and skill gaps that exist in the education of planners in Australia. The knowledge gaps were predominantly surrounding issues of climate change and water management. The skill gaps highlighted were primarily surrounding critical thinking and independent inquiry. The majority of respondents acknowledged that both skills and knowledge were important for planners to have in order to address environmental problems and that improvement is required in both areas.

Key implications of this research include the revision of curriculum of urban planning degrees to address these knowledge and skill gaps. It is recommended that further research in this field be undertaken in the future. This includes: 1) investigate the most effective way to address these identified gaps e.g. through existing curriculum, or through the development of additional subjects, or through a combination of the two; 2 ) an analysis of the existing planning curriculum at relevant Universities to address the extent to which they address 'environmental issues', and further highlight curriculum gaps to inform addressing these gaps; 3 ) a larger survey of planning professions periodically (every five years) to monitor how perceived planning education gaps and needs are changing over time;

4) it would be beneficial to investigate whether these knowledge and skill gaps are perceived by professionals in other countries. Given the increasing importance of environmental education, and the key role urban planners have with regards to influencing a more sustainable future, these results could be of particular benefit to urban planning and related environmental curricula, and to the implementation of sustainability. The study has implications for and interest to other professional degrees of which environmental sustainability is a component.

\section{Acknowledgements}

This research was undertaken by the author as part of a Graduate Certificate in University Teaching, with the Centre for Study of Higher Education at the University of Melbourne. The author thanks all the Planning Institute of Australia, the survey participants, and the following people for their assistance with this research Dr Kerri-Lee Harris, Ms Sarah Oberklaid, Ms Jenny Robins, Dr David Nichols and Ms Joan Greig.

\section{References}

Alonso, W. 1986. The unplanned paths of planning schools. Public Interest 82: 58-71. 
Association of University Leaders for a Sustainable Future. 1994. The Talloires Declaration: 10 point action plan. http://www.ulsf.org/talloires_declaration.html

Association of University Leaders for a Sustainable Future. 2008. The Association of University Leaders for a Sustainable Future: Welcome page. Association of University Leaders for a Sustainable Future. http://www.ulsf.org

Australian Bureau of Statistics. 2006. 1220.0 - Australian Standard Classification of Occupations: Unit Group 2523 Urban and Regional Planners. Canberra. http://www.abs.gov.au/ausstats/abs@.nsf/0/E471276D5EBE9B0FCA25697E00184D8D?opendocument

Australian Council of the Built Environment Design Professions Limited. 2008. Performance enhancement roadmap for the built environment design consulting industry. http://www.bedp.asn.au/docs/ICIP2008pdf.pdf.

Babbie, E. 2008. Qualitative field research. In The basics of social research, 312-347. Belmont, California: Wadsworth Publishing.

Beatley, T., and K. Manning. 1998. The ecology of place: Planning for environment, economy and community. Washington: Island Press.

Bekessy, S., M. Burgman, T. Wright, W.L. Filho and M. Smith. 2003. Universities and sustainability. Melbourne: The Australian Conservation Foundation.

Biggs, J., and C. Tang. 2007. Teaching for quality learning at university. Berkshire: Open University Press and SRHE.

Brockmann, M., Clarke, L., and Winch, C. 2008. Knowledge, skills, competence: European divergences in vocational education and training (VET) - the English, German and Dutch cases. Oxford Review of Education 34(5): $547-567$.

Campbell, S. 1996. Green cities, growing cities, just cities? Urban planning and the contradictions of sustainable development. Journal of the American Planning Association 62, no. 3: 296-312.

Carroll, J. E. 2005. Envisioning ecological sustainability: The need and a method. Environmental Values 4, no. 2: 1678.

Carson, R. 1963. Silent spring. London: Hamilton.

Cohen, B. 2007. Developing educational indicators that will guide students and institutions toward a sustainable future. New Directions for Institutional Research 134 (Summer): 83-94. 
Cooke, R., K. Miller and J. White. 2006. Understanding student expectations in developing environmental science courses. International Journal of Learning 13, no. 7: 9-20.

Diesendorf, M. 1997. Principles of ecological sustainability. In Human ecology, human economy: Ideas for an ecologically sustainable future, ed. M. Diesendorf and C. Hamilton, 64-97. St Leonards: Allen and Unwin.

Dobson, A. 1996. Environment sustainabilities: An analysis and a typology. Environmental Politics 5, no. 3: 401-428.

Elkington, J. 1997. Cannibals with forks. Oxford: Capstone Publishing Limited.

Feldman, M. M. A. 1994. Perloff revisited: Reassessing planning education in postmodern times. Journal of Planning Education and Research 13, no. 2: 89-103.

Freestone, R. 2007. A history of planning. In Planning Australia - An overview of urban and regional planning, ed. S. Thompson, 67-90. Melbourne: Cambridge University Press.

Freestone, R., P. Williams, S. Thompson, and K. Trembath. 2007. A quantitative approach to assessment of workbased learning outcomes: an urban planning application. Higher Education Research and Development 26, no. 4: 347-361.

Gleeson, B., and N. Low. 2000. Australian urban planning: New challenges, new agendas. Sydney: Allen and Unwin. Gunder, M. 2006. Sustainability: Planning's saving grace or road to perdition? Journal of Planning Education and Research 26: 208-221.

Hamnett, S. 1999. 50 Years of planning education in Australia. Australian Planner 36, no. 1: 5-6.

Holdsworth, S., C. Wyborn, S. Bekessy and I. Thomas. 2008. Professional development for education for sustainability: How advanced are Australian universities? International Journal of Sustainability in Higher Education 9, no. 2: 131 - 146.

Intergovernmental Panel on Climate Change. 2007. Climate Change 2007: The scientific basis. Contribution of working group I to the fourth assessment report of the Intergovernmental Panel on Climate Change. Cambridge: Cambridge University Press.

Jickling, B. 2003. Environmental education and environmental advocacy: Revisited. Journal of Environmental Education 34, no. 2: 20-27.

K. Kerkin. 2000. Designing a social space. Australian Planner 37, no. 1: 35-38. 
Kotval, Z. 2003. Teaching experiential learning in the urban planning curriculum. Journal of Geography in Higher Education 27, no. 3: 297-308.

Kwitko, L., and S. Thompson. 2002. Issues of difference and diversity in planning education. Australian Planner 39, no. 1: 30-36.

Lang, J., I. Thomas, and A. Wilson. 2006. Education for sustainability in Australian universities: Where is the action? Australian Journal of Environmental Education 22, no. 2: 45-58.

Lim, G.-C. 1993. Reforming education toward the global century. Environment and Planning B: Planning and Design 20: $567-576$.

Marshall, H. 2002. What do we do when we code data? Qualitative Research Journal 2, no. 1: 56-70.

Marshall, N. 2007. Planning as a profession. In Planning Australia - An overview of urban and regional planning, ed. S. Thompson, 49-65. Melbourne: Cambridge University Press.

Martin, E., and T. Beatley. 1993. Our relationship with the earth: Environmental ethics in planning education. Journal of Planning Education and Research 12: 117-126.

McManus, P. 1996. Contested terrains: Politics, stories and discourses of sustainability. Environmental Politics 5, no. 1: $48-73$

Meadows, D. H., D.L. Meadows, J. Randers and W.W.I. Behrens. 1972. The limits to growth: A report for the Club of Rome's Project on the predicament of mankind. London: Earth Island.

Niebanck, P. 1993. The shape of environmental planning education. Environment and Planning B: Planning and Design 20: 511-518.

Noonan, D., and I. Thomas. 2004. Greening universities in Australia: Progress and possibilities. Australian Journal of Environmental Education 20, no. 2: 67-79.

Perloff, H. 1956. Education of city planners: Past, present and future. Journal of the American Institute of Planners 22, no. 4: 186-217.

Planning Institute of Australia. 2002. Education policy for recognition of Australian planning qualifications. Canberra: Planning Institute of Australia National Secretariat.

Planning Institute of Australia. 2009. Planning Institute of Australia Urban and Regional Planning Chapter accredited courses. Canberra: Planning Institute of Australia. 
Ramsden, P. 2003. Learning to teach in higher education. London: Routledge Falmer.

Rapport, D. 1995. Ecosystem health: More than a metaphor? Environmental Values 4, no. 4: 287-309.

Richards, L. 2005. Qualitative data. In Handling qualitative data, 32-47. London: Sage.

Sandelowski, M. 1995. Sample size in qualitative research. Research in Nursing and Health 18: 179-183.

Sandercock, L. 1997. The planner tamed. Australian Planner 34, no. 4: 90-95.

Shephard, K. 2008. Higher education for sustainability: seeking affective learning outcomes. International Journal of Sustainability in Higher Education 9, no. 1: 87-98.

Sherran, K. 2006. Core issues reflections on sustainability in Australian university coursework programs. International Journal of Sustainability in Higher Education 7, no. 4: 400-413.

Sherran, K. 2008a. Higher environmental education: Core disciplines and the transition to sustainability. Australasian Journal of Environmental Sustainability 15: 190-196.

Sherran, K. 2008b. A history of the future of higher education for sustainable development. Environmental Education Research 14, no. 3: 238-256.

Smyth, J. C. 2006. Environment and education: A view of a changing scene. Environmental Education Research 12, no. 3-4: 247-264.

Stevenson, R. B. 2007. Schooling and environmental education: Contradictions in purpose and practice. Environmental Education Research 13, no. 2:139-153.

Thompson, S. 2007. What is Planning? In Planning Australia - An overview of urban and regional planning, ed. S. Thompson, 11-27. Melbourne: Cambridge University Press.

Toohey, S. 1999. Designing courses for higher education. Buckingham: Open University Press and SRHE. United Nations Educational Scientific and Cultural Organisation. 2008. Education for sustainable development. United Nations Decade (2005-2014). Geneva: UNESCO.

Vasey-Ellis, N. 2009. Planning for climate change in coastal Victoria. Urban Policy and Research 27, no. 2: 159-171. Vipond, O. 2000. Patterns in planning education, 1997-1999. Australian Planner 37, no. 4: 174-179.

Wheeler, S. M. 2004. Planning for sustainability: Creating livable, equitable and ecological communities. Milton Park, Oxon: Routledge. 
Wolfe, V. L. 2001. A survey of the environmental education of students in non-environmental majors at four-year institutions in the USA. International Journal of Sustainability in Higher Education 2, no. 4: 301-315.

World Commission on Environment and Development. 1987. Our common future. Oxford: Oxford University Press.

Wright, T. 2004. The evolution of sustainability declarations in higher education. In Higher education and the challenge of sustainability: Problematics, promise, and practice, ed. P. B. Corcoran and A. E. J. Wals, 7-20. Dordrecht: Kluwer Academic Publishers. 
Table 2. Perceived shortfalls in current planning education in Australia

\begin{tabular}{ll}
\hline FACTOR & Number of respondents \\
\hline Environmental issues & 10 \\
Removed from practice / reality & 5 \\
Critical thinking & 4 \\
Cultural & 3 \\
Urban - rural relations & 2 \\
Land use and transport planning & 2 \\
Interdisciplinary understanding & 2 \\
International perspective & 2 \\
Time management / people skills & 2 \\
Sustainability & 2 \\
Continual education & 2 \\
Design & 2 \\
Socio-economic issues & 2 \\
Heritage & 1 \\
Theory & 1 \\
GIS & 1 \\
Indigenous & 1 \\
Other & 6 \\
\hline Note: Question was - Do you perceivether are shotfals incurrent
\end{tabular}

Note: Question was - 'Do you perceive there are shortfalls in current urban planning education in Australia?' If yes, please detail the shortfalls you perceive. Responses were coded into the categories presented in this table. 


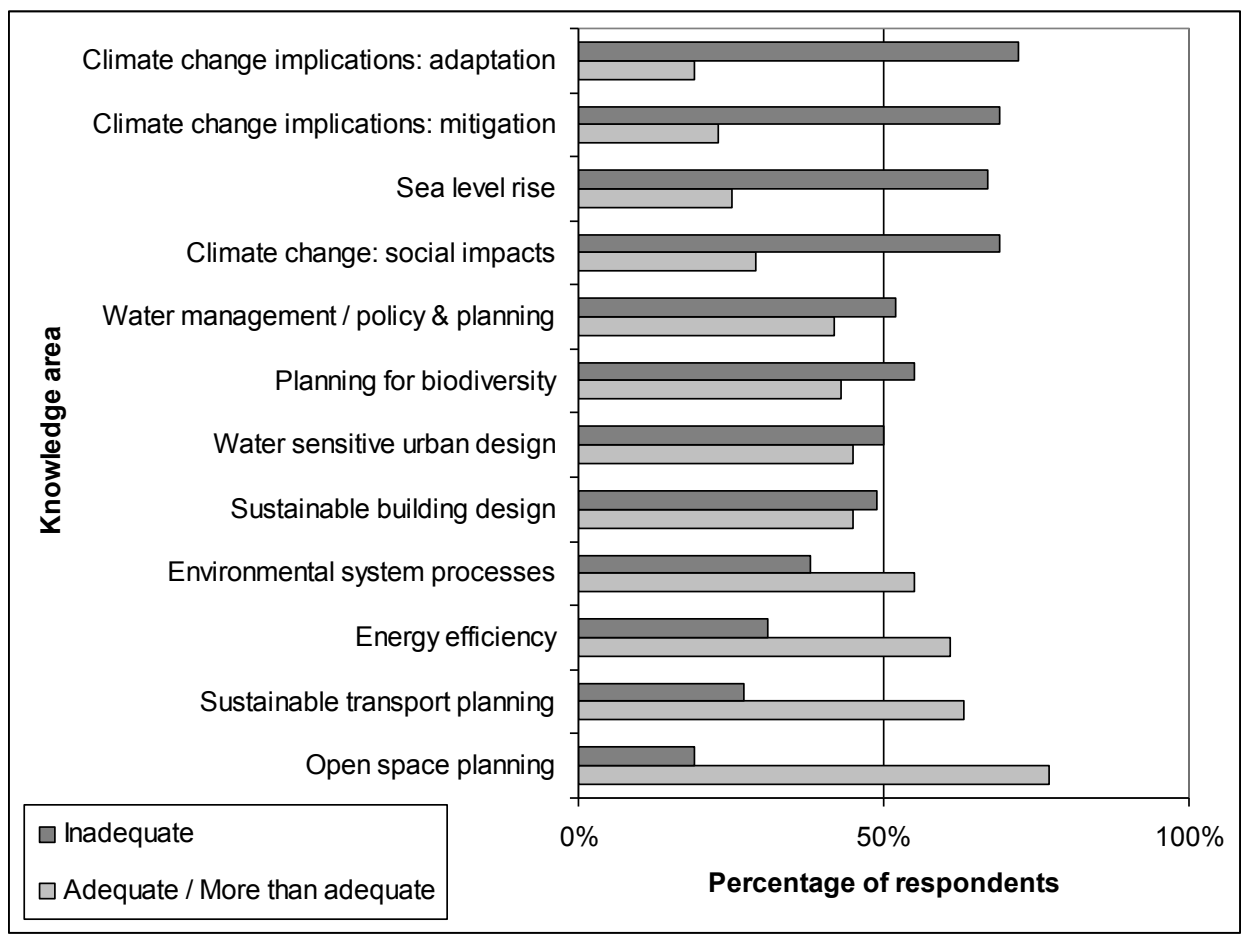

Figure 1. Respondents' perception of environmental knowledge adequacies of planners 


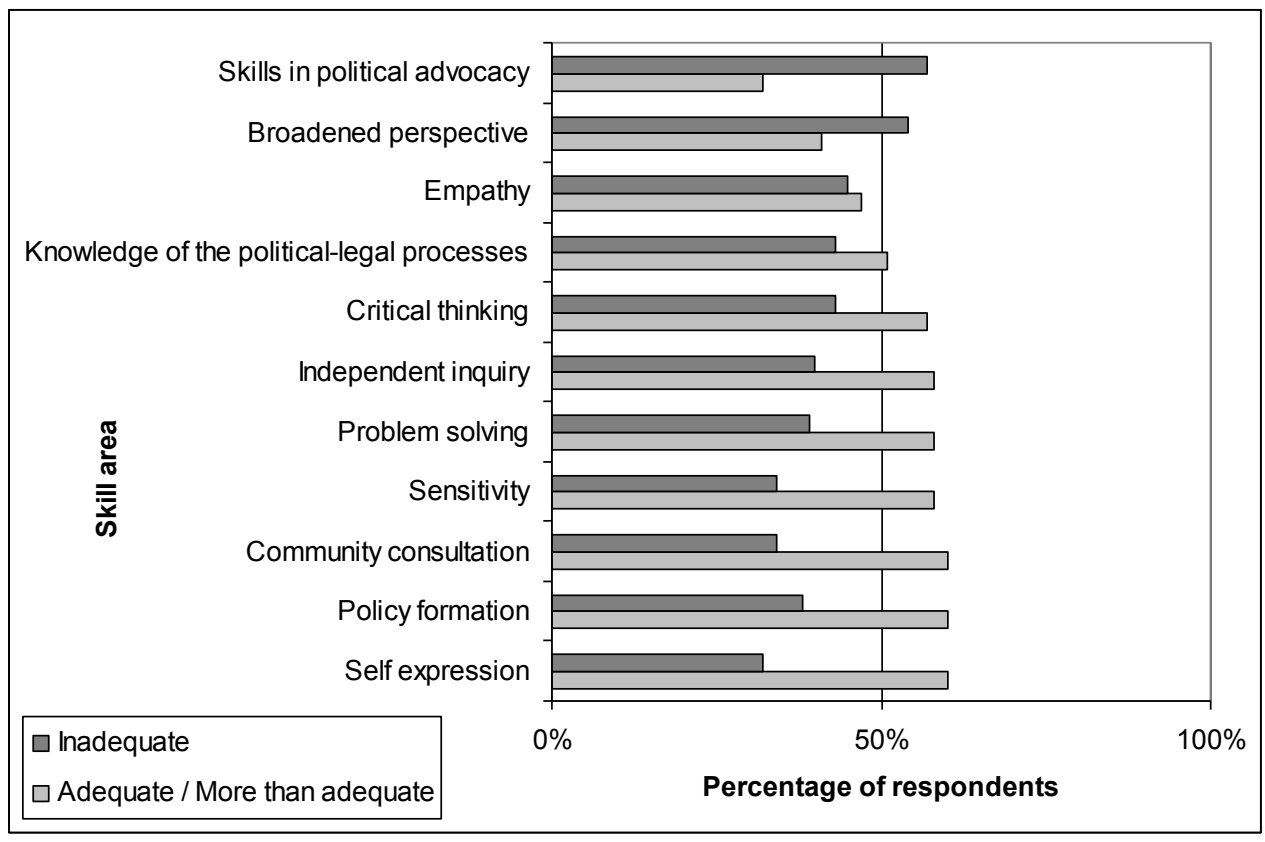

Figure 2. Respondents' perception of environmental skill adequacies of planners 
Table 1. Employment details of survey respondents

\begin{tabular}{ll}
\hline FACTOR & Number of respondents \\
\hline State & \\
\hline Victoria & 34 \\
New South Wales & 8 \\
Queensland & 3 \\
South Australia & 1 \\
ACT & 1 \\
Western Australia & 1 \\
\hline Work Location & \\
\hline Urban & 18 \\
Other & 10 \\
Rural & 8 \\
Coastal rural & 6 \\
Coastal urban & 4 \\
Urban fringe & 4 \\
\hline Work Sector & \\
\hline Private Practice & 19 \\
Local government & 14 \\
State government & 7 \\
Other & 6 \\
Academia & 4 \\
\hline
\end{tabular}


Table 3. Environmental knowledge areas to be addressed as a priority Environmental knowledge area

Wlimate change: mitigation, adaptation, social impacts; sea level rise 210

General knowledge of environmental system processes $\quad 8$

Planning for biodiversity

Sustainable building design

6

Sustainable transport planning

umber of respondents

Note: Question was - 'Which knowledge areas do you believe need to be addressed as a priority and why?' Responses were open-ended, thus they were coded into the categories presented in this table. 
Table 4. Environmental skill areas to be addressed as a priority

\begin{tabular}{ll}
\hline Skill area & Number of respondents \\
\hline Critical thinking & 13 \\
Independent inquiry & 8 \\
Community consultation & 6 \\
Problem solving & 4 \\
Political advocacy & 4 \\
Broadened perspectives & 3 \\
Communication (written and verbal) & 2 \\
Translation of science / technical issues into policy & 2 \\
Policy formation & 2 \\
Knowledge of political-legal processes & 2 \\
Sensitivity & 2 \\
Empathy & 1 \\
\hline
\end{tabular}

Note: Question was - 'Which skill areas do you believe need to be addressed as a priority and why?' Responses were openended, thus they were coded into the categories presented in this table. 


\section{University Library}

\section{- M M N E R VA A gateway to Melbourne's research publications}

Minerva Access is the Institutional Repository of The University of Melbourne

Author/s:

Hurlimann, AC

Title:

Responding to environmental challenges: an initial assessment of higher education curricula needs by Australian planning professionals

Date:

2009-01-01

Citation:

Hurlimann, A. C. (2009). Responding to environmental challenges: an initial assessment of higher education curricula needs by Australian planning professionals. ENVIRONMENTAL EDUCATION RESEARCH, 15 (6), pp.643-659. https://doi.org/10.1080/13504620903244159.

Persistent Link:

http://hdl.handle.net/11343/59113 